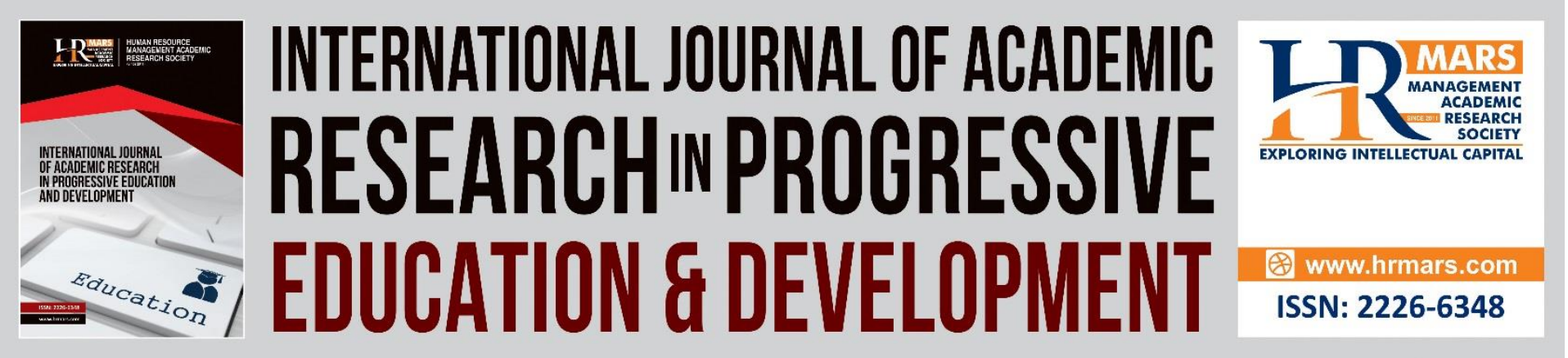

\title{
Development of a Novel Photography Blended Learning System (E-DUFOTO) towards a Successful Learning
}

\author{
Aliza Adnan, Rosseni Din, Nabilah Othman, Siti Farahin Ahmad Nawawi, \\ Roziah Md Amin
}

To Link this Article: http://dx.doi.org/10.6007/IJARPED/v11-i1/12022

DOI:10.6007/IJARPED/v11-i1/12022

Received: 01 November 2021, Revised: 28 November 2021, Accepted: 24 December 2021

Published Online: 22 January 2022

In-Text Citation: (Adnan et al., 2022)

To Cite this Article: Adnan, A., Din, R., Othman, N., Nawawi, S. F. A., \& Amin, R. M. (2022). Development of a Novel Photography Blended Learning System (E-DUFOTO) towards a Successful Learning. International Journal of Academic Research in Business and Social Sciences, 12(1), 247-262.

\footnotetext{
Copyright: (C) 2022 The Author(s)

Published by Human Resource Management Academic Research Society (www.hrmars.com)

This article is published under the Creative Commons Attribution (CC BY 4.0) license. Anyone may reproduce, distribute, translate and create derivative works of this article (for both commercial and non-commercial purposes), subject to full attribution to the original publication and authors. The full terms of this license may be seen

at: http://creativecommons.org/licences/by/4.0/legalcode
}

Vol. 11(1) 2022, Pg. 247 - 262

Full Terms \& Conditions of access and use can be found at http://hrmars.com/index.php/pages/detail/publication-ethics 


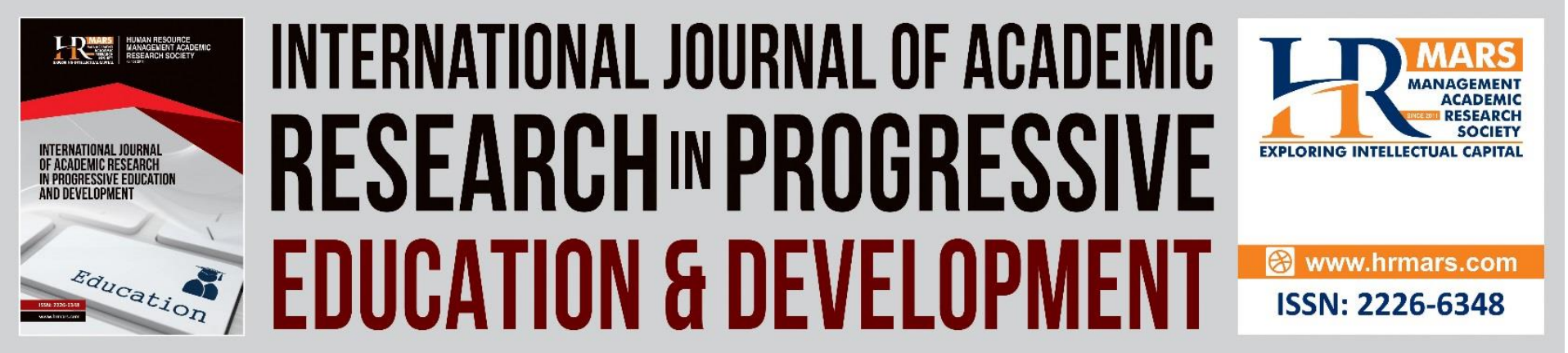

\title{
Development of a Novel Photography Blended Learning System (E-DUFOTO) towards a Successful Learning
}

\author{
Aliza Adnan \\ Institut Pendidikan Guru Kampus Ilmu Khas Cheras, Kuala Lumpur, Malaysia \\ Email: aliza.ipik@gmail.com
}

\section{Rosseni Din}

STEM Enculturation Centre, Faculty of Education,Universiti Kebangsaan Malaysia, 43600 UKM Bangi, Selangor, Malaysia

Email: rosseni@ukm.edu.my

\section{Nabilah Othman}

Information Technology \& Resources Module, Faculty of Education, Universiti Kebangsaan Malaysia, 43600 UKM Bangi, Selangor, Malaysia

Email: cik.nabilah001@gmail.com

\section{Siti Farahin Ahmad Nawawi}

Information Technology \& Resources Module, Faculty of Education, Universiti Kebangsaan Malaysia, 43600 UKM Bangi, Selangor, Malaysia

Email: farahinnawawi@gmail.com

\section{Roziah Md Amin}

Information Technology \& Resources Module, Faculty of Education, Universiti Kebangsaan Malaysia, 43600 UKM Bangi, Selangor, Malaysia

Email: roziahma@gmail.com

\begin{abstract}
Pedagogical innovation using online technology gives advantages in improving student's achievement and creating meaningful learning. The aim of this study is to develop e-DuFoto in producing meaningful learning and to enhance the skills of the basic techniques of photography among trainee teachers. This research involved feasibility study, needs analysis, design, development, implementation, evaluation and modelling of 100 trainee teachers. Questionnaires, group interviews protocol and assignment were used in data collection. Usefulness of e-DuFoto was tested on the aspect of design, pedagogy, content quality,
\end{abstract}


functionality and self-access. Usefulness data of e-DuFoto System was measured descriptively using mean. Final assessment was done using a questionnaire. The data were analyzed using the Partial Least Squares Structural Equation Modeling (PLS-SEM) technique to obtain three measurement models with the recommended loading value for the three latent variables. The structural equation modelling was applied to test the hypotheses of the study. Finding showed e-DuFoto System (i) has high usefulness with an overall average exceeding 4.50 mean (ii) blended learning has a very significant effect on the basic mastery of Photography skills and significant level for meaningful learning. Overall, the use of e-Dufoto System provide a new dimension in the online learning approach at Institute of Teacher Education to enhance students' mastery of basic skills of Photography techniques.

Keywords: Blended Learning, Meaningful Learning, Mastery, Photography, Achievement

\section{Introduction}

In order to promote learning transfer, learning tasks should be situated in a meaningful and real-world context or simulated through case-based or problem-based examples of the real world (Karagiorgi \& Symeou, 2005). Exposing students to activities where they work closely with their peers in online classes through meaningful collaborative learning and informal conversations leads to deeper thought development and knowledge construction (Barkley et al., 2014). Therefore, the achievement of learning outcomes is not only based on achievement in the examination but should be measured from the knowledge, skills and experience gained. Achieving learning outcomes needs specific experiences to be provided to the students. As a benchmark in learning process, learning outcomes guide the learners to know, understand, achieve and be able to demonstrate at the end of the courses. According to Carter Andrews et al (2021), learning outcomes in a flipped classroom produced greater effects compared to traditional classroom where students achieved higher input and better satisfaction of the environment. The main aim of the Malaysian Education Blueprint 2013-2025 is to improve the quality of education and learning outcome in Malaysia. It was revised in 2015 with the aim to enhance the competitiveness of graduates through transferable skills and meaningful learning. Blended learning and online learning are the catalysts for digital skills and technology targeted at the National Transformation 2050 (TN50) to create a generation of highly competitive and knowledgeable students. Global Online Learning (GOL) which was introduced in the Malaysian Education Blueprint for Higher Education (2015-2025) become an important catalyst for achieving Malaysia's goals in terms of access, quality and efficiency in higher education. GOL incorporates customized learning models (when face-to-face teaching is combined with computer-based learning) that can enhance the quality of teaching and learning by increasing student engagement. Mixed or combined learning can enhance meaningful learning.

As an institution that produces future teachers, Institute of Teacher Education (IPG) need to constantly implement the modifications of teaching tools to ensure recruitment of skilled teachers. The Technology in Teaching and Learning course expose trainee teachers to media and technology use in teaching and learning. Photography is one of the skills need to be mastered by trainee teacher in developing the visual arts and documentation of their learning activities. To produce good picture, trainee teachers need to acquire skills in shooting composition and shooting technique. Some trainee teacher faced trouble in acquiring these skills. The problems of the study can be identified in two aspects: the difficulty of learning photography and the constraint in current learning approach. Trainee teachers are not provided with suitable modules and sufficient cameras to do hands on activities. The duration 
of the course is not sufficient to make trainee teacher become a good Photographer. The current teaching and learning approach does not encourage trainee teachers to actively engage in learning activities. Face to face activities between lecturer and students does not provide continuity of learning outside the classroom. Technology is used as a medium of presentation and does not promote collaboration among students in class. Due to issue faced in current learning environment, a new approach in learning should be designed to create meaningful learning among students in terms of knowledge and skills in photography. This study objectively focused on three research objectives (RO):

RO1 develop develop a Photography Blended Learning System (e-DuFoto) that would contribute to meaningful learning and mastery of the basics of Photography.

RO2 identify effect of eDufoto on meaningful learning

RO3 identify effect of eDufoto on mastery of photography basic skills

\section{Blended Learning}

To create meaningful learning among students, continuity of learning in and out of the classroom must be established (Huang \& Chiu 2014; Huang, Chiu \& Chen, 2011). However, sometimes it is difficult to provide sufficient time and space for students to master the technology in teaching during formal classroom (Lambert \& Gong, 2010). Moreover, the results of the literature analysis and the problems with current learning methods indicate that there is still a gap in the learning approach that needs to be explored. Overall, many studies have explored the perceptions of blended learning (Bauk, 2015; Bower et al., 2015), advantages of blended learning (Biddix et al., 2015; Güzer \& Caner, 2014; Shams, 2013) and effectiveness of blended learning (Al-Madani, 2015). There are several studies that discuss blended learning and its relevance to achievement in various aspects. Among the aspects that have been implemented are aspects of the learning approach with student achievement (Lin, Tseng \& Chiang, 2017; Burhan, 2016), activities used in learning to integrate student achievement (Andri et al., 2015; Barkley, 2010) and online activities with achievement students (Shaw, 2010).

Ardoin et al (2014) studied Photography through a reflection journal writing approach. Sanif et al (2013) studied the effect of using digital photography modules on student creativity. In addition, Kloppenburg (2014) developed a Photography learning blog to increase student engagement in Photography classes using Web 2.0 (Woodlands Photography Online) approach. Furthermore, Abrahmov \& Ronen (2008) introduced online learning to overcome time constraints in the traditional learning approach. Based on the research that has been carried out, researchers found that not many studies have been carried out on the impact of blended learning on the achievement of Photography. According to Rahamat (2017) and Haili (2011), in order to implement effective blended learning approaches, learning elements need to be incorporated into learning activities to enhance students' engagement in learning activities. Din et al (2010) developed a hybrid e-Training for Technology course at Universiti Kebangsaan Malaysia. The results show that e-Learning has a great deal to do with meaningful learning (Din et al., 2010; 2014; 2015). A study conducted by Asfahani (2015) on an online module-based project (m-PAT) for Physics subjects showed that online learning contributes to meaningful learning. Most conventional approaches such as cooperative learning, projectbased learning, object-based learning can be used to achieve meaningful learning. However, not many studies see hybrid learning (blended learning) with meaningful learning (Din et al., 2010). According to Hamdan et al (2015), web-based teaching technology improves the quality of student achievement and constructs meaningful learning among students. 
However, studies on the link between meaningful learning and the use of Web 2.0 technology are still lacking.

Blended learning combines forms of direct and indirect online learning and usually involves the internet and intranet, while indirect learning occurs simultaneously within traditional classes (Oweis, 2018). Past studies showed that blended learning is one of the factors that motivate students to learn. This is because, students feel more comfortable to communicate and collaborate in class using online platform. Students tend to respond more frequently online compared to traditional face-to face classroom. According to Syafii \& Nurweni (2016), blended learning provides a lot of opportunities to explore students' needs and potentials. Blended learning also allows place and time flexibility for students' learning. Therefore, enhancing student learning experiences and motivations through blended learning have a great impact in improving student's motivation and achievement to learn (Zainon \& Yamat, 2021)

Blended learning methods using mobile technology support and enhance classroom learning with students of different cultures (Biddix et al., 2015). Güzer \& Caner (2014) proposed that constructivist and collaborative models integrated into the hybrid learning environment can enhance students' creativity. Students are able to learn according to their performance and achievements through learning using the Web 2.0 application and Learning Management System (Cavus \& Kanbul, 2014). Blended learning makes learning environments more effective in terms of achievement than conventional methods. However, not many studies have examined students' achievement using a blended approach based on the constructivist environment (Vernadakis et al., 2011).

\section{Meaningful Learning}

To make learning more effective, the environment must be based on meaningful learning and digital learning (Stover, 2012). This is in line with the worldwide education system that emphasizes the importance of pedagogical innovation using the latest technology to produce effective and meaningful learning outcomes (Hamdan et al., 2015). Learning outcomes will be more meaningful when students are able to master new knowledge and have the ability to associate new knowledge with existing knowledge in a meaningful way (Kengwee \& Wachira, 2008). Learning through memorization that does not encourage the establishment of important links and relationships. According to Belmont (2016) meaningful learning take place when a new learning can be associated with what the students already know. Meaningful learning is different from memorization learning that incorporates new information into the knowledge structure but has no interaction. Therefore, memorization was found not to support the understanding of the relationship with objects to establish the correct relation between new knowledge and existing knowledge to form meaningful learning (Belmont, 2016).

Meaningful learning is linked to the intrinsic aspirations of students, which are teaching-centered learning based on student interest. Authentic learning is referred to as a learning method that brings students to real life experiences. In fact, authentic learning and meaningful learning are interrelated. Meaningful learning is learning that is shaped by students and not knowledge transferred from teacher to student (Jonassen et al., 2008; Jonassen et al., 1999). Therefore, students need to acquire knowledge according to their 
needs and not rely solely on instructors or teachers to provide knowledge without knowing the relevance of that knowledge in their lives (Stover, 2012, Yogihati, 2010).

Jonassen \& Strobel (2006) identified five attributes for establishing meaningful learning, namely, cooperative learning, active learning, objective learning, authentic learning and constructive learning. Therefore, to create effective learning based on technology, learning must have all five of these attributes. According to Grabe \& Grabe (2008), active use of text, graphics, sounds and animations in the classroom can help students acquire and synthesize information. According to Jonassen et al (2006) learning activities using multimedia elements can create and spark meaningful learning. To create meaningful learning, learning and teaching activities require active, constructive, purposeful, authentic and cooperative student engagement. All of these attributes are independent and the use of technology can support all of these attributes to form meaningful learning (Din, 2010; Kengwee \& Wachira, 2008).

\section{Mastery of Basics Photography}

Student academic achievement is a key goal of success in teaching and learning. One of the contributing factors to students' academic achievement is the use of a learning approach that improves learning quality and access. Previous studies have shown that blended learning has a positive impact on students' learning quality and achievement. Nouby \& AlKhazali (2017) studied the effects of blended learning on learning achievement and deep learning for students at Arabian Gulf University. The results showed that there were significant score differences in pre and post tests using blended learning approach. Students participated actively in online learning activities provided through the Moodle application. Creating a learning community through discussion methods, electronic dialogue and cooperative learning activities helps students to complete assignments and facilitate their learning outcomes.

The Moodle platform was also used by Lin et al (2017) in a study on the approach of blended learning for mathematical subjects. The findings show that the use of blended learning has a positive effect on students' learning outcomes and attitudes towards learning mathematics. Students give positive feedback on math learning using Moodle. Al Madani (2015) found that the use of blended learning for language courses can improve student achievement and encourage critical thinking compared to traditional approaches.

In addition, McLaughlin (2015) studied the implementation of module integration for the subject of online Venous Thromboembolism (VTE) and face-to-face learning. The findings show that students' understanding and academic performance have increased after using blended learning. In addition, positive impacts on student engagement were also recorded. The online module on Venous Thromboembolism (VTE) contributes to active learning, complementing and reinforcing basic information in a way that enables students to synthesize, and understand complex ideas construction (McLaughlin, 2015). Studies on student satisfaction and achievement using blended learning were conducted by Melton et al (2009). The study was conducted in Health Course on a sample of 251 students. The study found that higher scores were obtained by using a current digital approach than traditional approaches. Students chosen to present using online platform.

Luna \& Winters (2017) studied the success of blended learning for Sociology subjects found that the use of blended learning and flipped pedagogy showed improved pre test and post test scores compared to conventional approaches. This approach has reduced the gap between students and increased students' active participation in the learning process. 
Vasbieva et al (2016) studied the impact of a blended learning approach on student achievement of English vocabulary subjects for ESL students at Financial University Russia. Achievement of students using blended learning is higher compared to conventional approaches. The pre- and post-test showed that blended learning had a positive effect on students' vocabulary mastery. Based on these discussions, the following hypotheses have been developed:

$\mathrm{H} 1$ : Photography blended learning has a significant impact on meaningful learning. $\mathrm{H} 2$ : Photography blended learning has a significant impact on the mastery of Photography

\section{Research Methodology}

The products of this study were produced through the Design and Developmental Research, DDR (Richey \& Client, 2004). Evaluation of research products using survey method. This study was conducted based on the Participatory Design methods and adaptation of the SPP IV Design Model (Din et al., 2010; 2017). Before embarking on the model development process, the researcher needs to design the teaching media that will be integrated, the testing and evaluation instruments to be used and integrated teaching materials or media to form a teaching system. The teaching system in the context of this study is a combination of the use of Schoology, the learning web using the Wordpress platform and the Modules using the Ms Word application.

The model has six phases; Phase 1: Feasibility studies, Phase 2: Need analysis, Phase 3: System Design, Phase 4: Development, Phase 5: Training and Implementation and Phase 6: Evaluation, System Maintenance and Model Development. Usability testing 1 was performed in the development phase to test for system errors. In the Training phase, usability assessment is carried out to identify the usefulness of the e-DuFoto system to students. Usefulness of the e-DuFoto system was conducted on 37 students from IPG campus. Usability assessments were analyzed using SPSS 23. The final assessment was undertaken in the assessment and modeling phase to identify the contribution of Photography blended learning to meaningful learning and mastery of basic Photography. Data was collected from 100 sample students from three different IPG campus through questionnaire. The e-DuFoto questionnaire is divided into three sections, Part $A$ is about demographic information, Part $B$ is for measuring learners' learning and Part $C$ is for measuring meaningful learning. The eDuFoto questionnaire has 57 items adapted and modified from the MiNT (Meaningful hybrid e-Training) instrument (Din 2012) to measure mix learning and meaningful learning. The data collected were analyzed using Smart PLS 3.0.

In this study, questionnaire was used empirically as the main instrument in this study to test two hypotheses mentioned before. The e-DuFoto questionnaire measures five components of blended learning namely content, delivery, structure, services and learning outcomes. Meaningful learning was measured by five components; cooperative, active, authentic, constructive and objective. All items in the Part B questionnaire were measured using a likert scale, namely (1) Strongly Disagree, (2) Disagree, (3)Less Agree, (4) Agree, and (5) Strongly Agree. Part C in the questionnaire measured item using rubric.

\section{Data Analysis}

The data were analysed using Smart PLS version 3.2.6, a software developed by Ringle, Wende \& Becker (2015), which is a variance-based structural equation modelling (SEM). It is a better choice to present the analysis instead of covariance-based SEM due to the purpose of this study is to predict the relationship between variables tested in the research model rather 
than reproducing the covariance matrix to achieve model fit (Hair et al., 2014). On the other hand, Smart PLS is also suitable for data which do not meet the normality requirements. As proposed by Hair et al. (2017), the study was tested the multivariate normality by looking at the skewness and kurtosis using the software available; https://webpower.psychstat.org/models/kurtosis/results.php?url=35c61a7b38ba2b14fd093 1913493 bbc9.

The analysis in PLS was divided into two stages: measurement model and structural model. Measurement model involves the assessment of the reliability and validity of the measures. In the measurement model, reliability was assessed by examining the Composite Reliability (CR) while validity was assessed in convergent validity and discriminant validity. After confirming the validities, the structural model will be used to test the hypotheses. The bootstrapping procedure with 5000 resamples which is higher than the original sample of the study, following the procedure mentioned by Hair et al. (2017) to determine the significance level of loadings and path coefficients before testing the measurement model. Since the data was collected using a single source, though common method variance should be an issue for the study and the proposed methods on how to remedy this common method variance (CMV) issue, thus, this study adopted Harman's Single factor test to ensure that the common method variance is not problematic. The CMV is a serious issue if the first factor explained the majority of the explained variance (Podsakoff et al., 2003). The un-rotated factor analysis in the study shows that the 1 st factor only explained $28.531 \%$ of the total variance, thus the CMV is not an issue for this study.

\section{Findings}

\section{Measurement Model}

To confirm the measurement model, two types of validity must meet the convergent validity and discriminant validity. Convergent validity measures the degree to which multiple items measure the same concepts in agreement (Hair et al., 2017). In order to assess the convergent validity of the measurement model, the loadings, AVE and CR must meet the threshold value (Chin 2010; Hair, Ringle \& Sarstedt, 2011). Hair et al (2017) proposed that loading must exceed 0.5 and CR must higher than 0.7. Table 1 shows that the loadings, AVEs and the CR of the constructs were higher than the threshold value mentioned by Hair et al. (2014). Therefore, convergent validity requirements are relevant for the study. The discriminant validity is the extent to which a construct is truly distinct from other constructs by empirical standards (Hair et al., 2017). 
INTERNATIONAL JOURNAL OF ACADEMIC RESEARCH IN PROGRESSIVE EDUCATION AND DEVELOPMENT

Vol. 11, No. 1, 2022, E-ISSN: 2226-6348 ㄷ 2022 HRMARS

Table 1: Validation of the measurement scales

\begin{tabular}{|c|c|c|c|c|}
\hline Construct & Item & Loading & CR & AVE \\
\hline \multirow[t]{7}{*}{ Content } & cont1 & 0.873 & 0.933 & 0.699 \\
\hline & cont2 & 0.790 & & \\
\hline & cont2 & 0.790 & & \\
\hline & cont3 & 0.888 & & \\
\hline & cont4 & 0.802 & & \\
\hline & cont5 & 0.863 & & \\
\hline & cont6 & 0.795 & & \\
\hline \multirow[t]{6}{*}{ Services } & serv1 & 0.852 & 0.912 & 0.634 \\
\hline & serv2 & 0.839 & & \\
\hline & serv3 & 0.806 & & \\
\hline & serv4 & 0.795 & & \\
\hline & serv5 & 0.739 & & \\
\hline & serv6 & 0.737 & & \\
\hline \multirow[t]{6}{*}{ Delivery } & dlvery1 & 0.744 & 0.915 & 0.644 \\
\hline & dlvery2 & 0.829 & & \\
\hline & dlvery3 & 0.790 & & \\
\hline & dlvery4 & 0.870 & & \\
\hline & dlvery5 & 0.750 & & \\
\hline & dlvery6 & 0.824 & & \\
\hline \multirow[t]{6}{*}{ Structure } & stru2 & 0.796 & 0.939 & 0.721 \\
\hline & stru3 & 0.843 & & \\
\hline & stru4 & 0.822 & & \\
\hline & stru5 & 0.898 & & \\
\hline & stru6 & 0.869 & & \\
\hline & stru7 & 0.863 & & \\
\hline \multirow[t]{3}{*}{ Learning outcome } & 103 & 0.890 & 0.868 & 0.687 \\
\hline & lo4 & 0.826 & & \\
\hline & 105 & 0.765 & & \\
\hline \multirow{5}{*}{$\begin{array}{l}\text { Mastery } \\
\text { Photography }\end{array}$} & $\mathrm{mp1}$ & 0.818 & 0.892 & 0.675 \\
\hline & & & & \\
\hline & $\mathrm{mp2}$ & 0.846 & & \\
\hline & mp3 & 0.846 & & \\
\hline & $\mathrm{mp} 4$ & 0.775 & & \\
\hline \multirow[t]{4}{*}{ Active } & act1 & 0.649 & 0.845 & 0.584 \\
\hline & act3 & 0.911 & & \\
\hline & act4 & 0.840 & & \\
\hline & act5 & 0.616 & & \\
\hline \multirow[t]{3}{*}{ Authentic } & aut1 & 0.801 & 0.757 & 0.512 \\
\hline & aut2 & 0.659 & & \\
\hline & aut3 & 0.678 & & \\
\hline \multirow[t]{2}{*}{ Constructive } & const2 & 0.858 & 0.834 & 0.627 \\
\hline & const3 & 0.763 & & \\
\hline Cooperative & coop1 & 0.753 & 0.763 & 0.617 \\
\hline
\end{tabular}




\begin{tabular}{lllll} 
& coop2 & 0.816 & & \\
\hline Objective & obj2 & 0.754 & 0.799 & 0.571 \\
& obj3 & 0.804 & & \\
& obj6 & 0.706 & & \\
\hline
\end{tabular}

\section{Structural Model}

Before testing the structural model, it is crucial to confirm that there is no collinearity issue in the structural model. Table 2 below shows that the VIF value for each construct is lower than the conservative value of 5.0 (Hair et al., 2013). Hence, it also indicates that collinearity is not an issue for the study.

\begin{tabular}{lll} 
Table 2: Collinearity test & \\
\hline Model & & VIF \\
\hline Blended learning (e-DuFoto) & Content & 2.618 \\
& Media & 2.399 \\
& Services & 3.304 \\
& Structure & 3.676 \\
& Learning & 2.206 \\
& outcome & \\
Meaningful Learning & Cooperative & 1.349 \\
& Constructive & 1.904 \\
& Active & 1.260 \\
& Objective & 1.638 \\
& Authentic & 1.860 \\
\hline
\end{tabular}

After confirming the measurement model and the collinearity issue, next is the assessment of structural model. Table 3 shows the result of the path coefficient assessment using the bootstrapping procedure to test the hypotheses generated from the research model. Typically the critical values used for one-tailed tests were 1.645 (significant level 5\%) and 2.33 (significant level 1\%). Findings in Table 3 show that $t$ values are significant at the $1 \%$ level for Hypothesis 1 and Hypothesis 2. Therefore, all hypotheses tested were supported. The findings also show that blended learning has a significant impact on meaningful learning and blended learning has a significant impact on the mastery of Photography.

Table 3: The summary of hypotheses testing results

\begin{tabular}{|c|c|c|c|c|c|c|c|}
\hline & & $\begin{array}{l}\text { Standard } \\
\text { beta } \beta\end{array}$ & $\begin{array}{l}\text { Standard } \\
\text { error }\end{array}$ & T Value & LL & UL & Result \\
\hline $\begin{array}{l}\text { E-DuFoto } \\
\text { Meaningful } \\
\text { Learning }\end{array}$ & $->$ & 0.369 & 0.095 & $3.919 * *$ & 0.200 & 0.511 & supported \\
\hline $\begin{array}{l}\text { e-DuFoto } \\
\text { Mastery } \\
\text { Photography }\end{array}$ & $\begin{array}{l}-> \\
\text { of }\end{array}$ & 0.837 & 0.036 & $\begin{array}{l}22.517^{*} \\
*\end{array}$ & 0.772 & 0.889 & supported \\
\hline
\end{tabular}

Note: LL, Lower limit ; UL, Upper Limit at $95 \%$ and $99 \%$ confidence interval. ${ }^{*} p<0.05$ (1.645):** $p<0.01(2.33)$, 
DEVELOPMENT

Vol. 11, No. 1, 2022, E-ISSN: 2226-6348 @ 2022 HRMARS

Figure 1 shows the structural model on the impact of blended learning on meaningful learning and mastery of basic Photography. The path coefficient shows the relationship between blended learning and meaningful learning ( $\beta=0.369, t=3.919)$ and blended learning and mastery of basic Photography $(\beta=0.837, t=0.837)$. According to $\beta$ value, blended learning has higher significant impact on the mastery of basic Photography. The use of blended learning gives a big impact on students' achievement based on student assignment scores. Mark of student assignments and student feedback also support the positive impact of using the e-DuFoto system on student achievement.

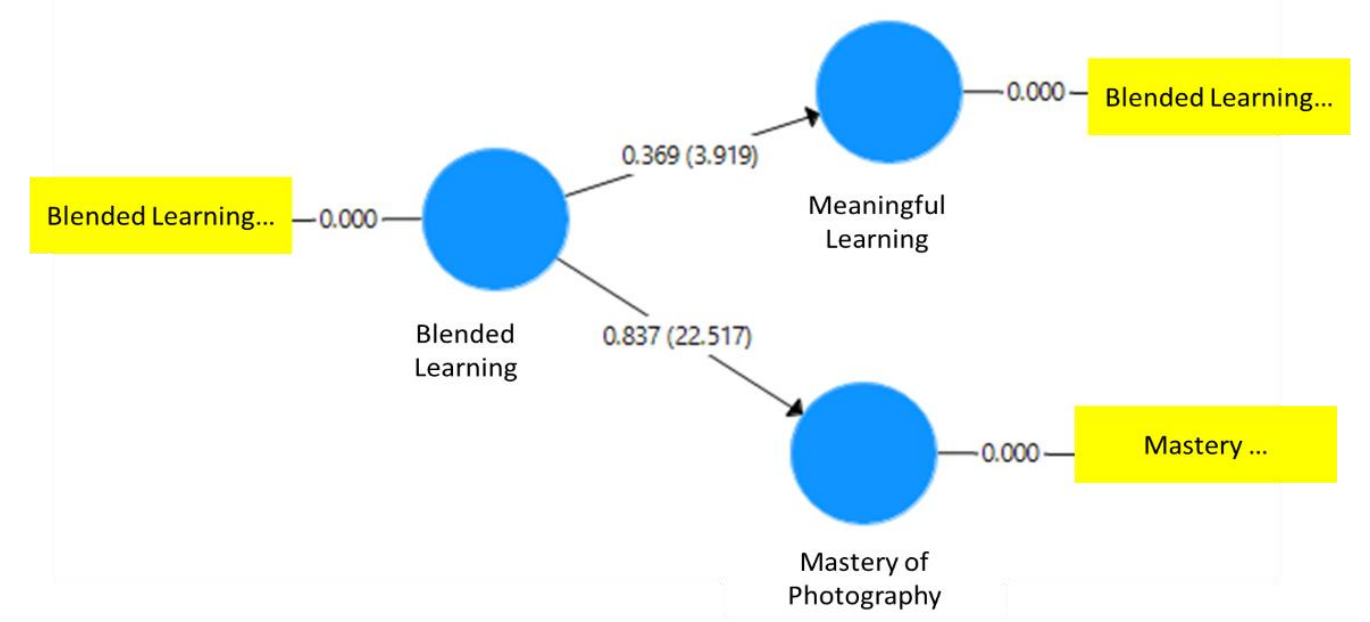

Figure 1: Structural model analysis (internal model) - bootstrapping procedure

\section{Discussion}

The e-DuFoto system was developed using meaningful learning and blended learning approach. Meaningful learning elements (cooperative, constructive, active, authoritative and objective) applied in the development of the Web of Photography and basic module of Photography can stimulate meaningful learning experience for students. Implementation of e-DuFoto System development was carried out in a face-to-face and online activities. Minimalist Theory and Constructivism theory are integrated into the development of the Web of Photography and the basic module of Photography in line with the aim of self-directed and student-centered learning.

The usefulness of the e-DuFoto was being evaluated in terms of design, pedagogy, content quality, functionality, self-access and functionality. The test results showed that the mean of all aspects evaluated was above the mean level score above 4.50. Functional elements ( $\min 4.73$ ) and content quality elements $(\min 4.70)$ showed the highest scores. The overall findings indicated that the Photography Blended Learning System has the potential to be used as a learning support tool in IPG. The validity and reliability of the measurement construct meet the validity values set. The accuracy and relevance of the structural model can be proven from the values of $R^{2}, f^{2}$ and $Q^{2}$ (Table 4 ). 
Table 4: Relationship of research construct value of $R$ square $\left(R^{2}\right)$ effect size $\left(f^{2}\right)$ and predictive relevance $\left(Q^{2}\right)$.

\begin{tabular}{lcccc}
\hline & $\mathrm{t}$ & $\mathrm{R}^{2}$ & $\mathrm{Q}^{2}$ & $\mathrm{f}^{2}$ \\
\hline $\begin{array}{l}\text { Blended learning> } \\
\text { Meaningful Learning }\end{array}$ & 3.919 & 0.127 & 0.114 & 0.157 \\
$\begin{array}{l}\text { Blended learning }> \\
\text { Mastery of basic }\end{array}$ & 22.517 & 0.697 & 0.677 & 2.332 \\
\begin{tabular}{l} 
Photography \\
\hline
\end{tabular} & & & & \\
\hline
\end{tabular}

The findings of this study showed that the $Q^{2}$ value was relevant at high level for the construct of mastery Photography and at low level for the meaningful learning construct. The impact of e-DuFoto on the mastery of photography skills can be assessed through $R^{2}$ and $f^{2}$ values. The results showed that the value of $R^{2}$ is 0.697 . This finding explains that the use of the e-DuFoto System in teaching and learning has a significant impact on students' mastery of basic Photography. Referring to Table 5 , the values of $R^{2}$ and $f^{2}$, for meaningful learning were small. The value of $R^{2}$ for meaningful learning is 0.127 , this value showed that the effect size $f^{2}$ value for blended learning on meaningful learning was small. However, based on empirical analysis of $t$ values, the meaning of learning that was active, constructive, objective, authentic and cooperative has a significant influence on the formation of meaningful learning. The analysis of coefficients based on coefficient of determination $\left(R^{2}\right)$, effect size, $\left(f^{2}\right)$ predictive relevance $\left(Q^{2}\right)$ showed that blended learning had a significant impact on the basics of photography and had little effect on meaningful learning.Future studies should thoroughly examine this research framework in other settings to generate better understanding. The blended learning method can be applied to other topics or other courses that involve practical activities such as video clip production and audio editing. Both of these are skills that students develop in the teaching medium. The impact of blended learning can be studied in relation to other constructs such as transferable skills or high-level thinking skills to see the effects of blended learning from a more dynamic perspective. The instruments of this study can be extended to measure civilization learning, meaningful learning and achievement in different study populations such as the Institute of Public Higher Education, the Institute of Private Public Studies and the Polytechnic. The differences in the learning environment, the facilities, and the lecturers involved can provide research findings with new inputs for the future. Comparative study of blended learning strategies and other traditional learning strategies such as project-based learning, problem-based learning, case study learning, and other strategies should be conducted to see which form of learning strategies best suit students' needs.

\section{Conclusion}

Through this study, a new novelty can be generated through models of measurement of blended learning, meaningful learning and student achievement. The advantages of blended learning have been acknowledged by many academics and researchers both locally and abroad. Online learning can support learning seamlessly and provide a variety of positive impacts on teaching and learning pedagogical innovations. Integrated learning can provide a flexible learning space, encourage self-directed learning and enhance students' knowledge and skills. The combination of conventional and online methods can make learning and teaching more meaningful. Students can actively participate in the learning process. Online 
applications can provide students with authentic experiences. Practical activities can be performed better through the support of online applications and online video. Blended learning can be integrated into subjects that involve practical activities. Blended learning can be a good choice for lecturers since it can increase student understanding and motivation in learning. Blended learning opens up various possibilities for learning methods that are more flexible to students. Flexibilities of class setting in blended learning approach contributes high motivation on students' learning. Therefore, it gradually contribute to students achievement and performance. As a whole, the integrated learning approach using blended learning can optimize learning outcomes and enhance student achievement in learning including Photography topics.

\section{Acknowledgement}

Appreciation and many thanks to Centre of Research for STEM Enculturation, Faculty of Education, Universiti Kebangsaan Malaysia, the Ministry of Education and the Malaysian Government for grant GG-2021-002. Many thanks to all researchers under the project and Personalized Education Research Group for the financial, intellectual, spiritual and moral support.

\section{References}

Karagiorgi, Y., \& Symeou, L. (2005). Translating constructivism into instructional design: Potential and limitations. Educational Technology \& Society. 8(1), 17-27. https://www.jstor.org/stable/jeductechsoci.8.1.17

Barkley, J. E., Salvy, S. J., Sanders, G. J., Dey, S., Von Carlowitz, K. P., \& Williamson, M. L. (2014) Peer influence and physical activity behavior in young children: an experimental study.Journal of Physical Activity and Health. 11(2), 404-409. https://doi.org/10.1123/jpah.2011-0376

Carter Andrews, D. J., Richmond, G., \& Marciano, J. E. (2021). The Teacher Support Imperative: Teacher Education and the Pedagogy of Connection. Journal of Teacher Education. 72(3), 267-270. https://doi.org/10.1177/00224871211005950

Huang, Y. M., \& Chiu, P. S. (2014). The effectiveness of a meaningful learning-based evaluation model for context-aware mobile learning. British Journal of Educational Technology. 46(2), 437-447. https://doi.org/10.1111/bjet.12147

Huang, Y. M., Chiu, P. S., Liu, T. C., \& Chen, T. S. (2011). The design and implementation of a meaningful learning-based evaluation method for ubiquitous learning. Computers \& Education. 57(4), 2291-2302. https://doi.org/10.1016/j.compedu.2011.05.023

Lambert, J., \& Gong, Y. (2010). $21^{\text {st }}$ century paradigms for pre-service teacher technology $\begin{array}{llll}\text { preparation. Computers in the Schools. 27(1), 54-70 } & \end{array}$ https://doi.org/10.1080/07380560903536272.

Bauk, S. I. (2015). Assessing students' perception of e-learning in blended environment: an experimental study. Procedia-Social and Behavioral Sciences. 191, 323-329. https://doi.org/10.1016/j.sbspro.2015.04.393

Bower, M., Dalgarno, B., Kennedy, G. E., Lee, M. J. W., \& Kenney, J. (2015). Design and Implementation Factors in Blended Synchronous Learning Environments: Outcomes from a Cross-Case Analysis. Computers \& Education. 86, 1-17. https://doi.org/10.1016/j.compedu.2015.03.006 
Biddix, J. P., Chung, C. J., \& Park, H. W. (2015). The hybrid shift: Evidencing a student-driven restructuring of the college classroom. Computers \& Education. 80, 162-175. https://doi.org/10.1016/j.compedu.2014.08.016

Güzer, B., \& Caner, H. (2014). The past, present and future of blended learning: an in depth analysis of literature. Procedia-Social and Behavioral Sciences. 116, 4596-4603. https://doi.org/10.1016/j.sbspro.2014.01.992

Shams, I. E. (2013). Hybrid learning and Iranian EFL learners' autonomy in vocabulary learning. Procedia-Social and Behavioral Sciences. 93, 1587-1592. https://doi.org/10.1016/j.sbspro.2013.10.086

Al-Madani, F. M. (2015). The effect of blended learning approach on fifth grade students' academic achievement in my beautiful language textbook and the development of their verbal creative thinking in Saudi Arabia. Journal of International Education Research. 11(4), 253-260. https://doi.org/10.19030/jier.v11i4.9459

Lin, Y. W., Tseng, C. L., \& Chiang, P. J. (2017). The effect of blended learning in Mathematics course. Eurasia Journal of Mathematics, Science \& Technology Education. 13(3), 741770. https://doi.org/10.12973/eurasia.2017.00641a

Burhan, N. M. (2016). Pembangunan dan penilaian Modul Tamadun Islam dan Tamadun Asia berasaskan strategi Blended Learning. (Unpublished doctoral dissertation). Universiti Kebangsaan Malaysia.

Andri, I., Christina, V., Panayiotis, Z., Tanja, A., Tomaz, K., \& Matija, P. (2015). Creative multimodal learning environments and blended interaction for problem-based activity in $\mathrm{HCl}$ education. TechTrends. 59(2), 47-56. https://doi.org/10.1007/s11528-015-08399

Barkley, S. G. (2010). Quality teaching in a culture of coaching. R\&L Education.

Shaw, J. G. A. (2010). study of students' perceptions of blended learning environments at a state-supported post secondary institution. (Unpublished doctoral dissertation). University of North Texas.

Ardoin, N. M., Digiano, M., Bundy, J., Chang, S., Holthuis, N., \& O'connor, K. (2014). Using digital photography and journaling in evaluation of field-based environmental education programs. Studies in Educational Evaluation. 41, 1-3. https://doi.org/10.1016/j.stueduc.2013.09.009

Sanif, S. N. A. M., Hussin, Z., Senom, F., Siraj, S., \& Putih, A. T. (2013). Nature exquisiteness based digital photography arts project for creativity enhancement among low achievers' students. (PROSFDak). Procedia-Social and Behavioral Sciences. 103, 675684. https://doi.org/10.1016/j.sbspro.2013.10.387

Kloppenburg, J. (2014). Creating an effective learning environment for a secondary school photography course. Graduate Theses and Dissertations, Vancouver Island University, Nanaimo, Canada.

Abrahmov, S. L., \& Ronen, M. (2008). Double blending: online theory with on-campus practice in photography instruction. Innovations in Education and Teaching International. 45(1), 3-14. https://doi.org/10.1080/14703290701757385

Rahamat, R. B., Shah P. M., Din, R., \& Abd, J. A. (2017). Students' readiness and perceptions towards using mobile technologies for learning the English language literature component. The English Teacher. 40, 68-84.

IPG. (2011). Gagasan baharu IPG. Institut Pendidikan Guru.

Din, R., Nordin, M. S., Abu, N. K., Ahmad, T. B. T., Jusoff, K., Johar, N. A., Zaman, K. M. F., Zakaria, M. S., Ahmad, M., Abdul Karim, A., \& Mastor, K. A. (2010). Development and 
validation of meaningful hybrid e-training model for computer education. International Journal of Computer Science and Information Technologies, 1(3), 179-184. http://irep.iium.edu.my/4812/

Din, R. (2014). Pembinaan dan Permodelan Sistem Pengajaran. Bangi: Penerbit Universiti Kebangsaan Malaysia.

Din, R. (2015). Forward from the Chief Editor: The Inaugural Issue of JPL. Journal of Personalized Learning. 1(1), i-iii. http://spaj.ukm.my/jplearning/index.php/jplearning/article/view/27

Zakaria, A., Salleh, A. M., Ismail, M. A., \& Ghavifekr, S. (2015). Promoting Meaningful Learning via Online Project-based Module. The International Journal of e-Learning and Higher Education (IJELHE). 6(1), 71-95. https://myjurnal.mohe.gov.my/public/articleview.php?id=107138

Hamdan, A., Din, R., Manaf, S. Z. A., Salleh, N. S. M., Kamsin, I. F., \& Ismail, N. M. (2015). Exploring the relationship between frequency use of Web 2.0 and meaningful learning attributes. Journal of Technical Education and Training. 7(1), 50-66. https://penerbit.uthm.edu.my/ojs/index.php/JTET/article/view/1025

Oweis, T. I. (2018). Effects of using a blended learning method on students' achievement and motivation to learn English in Jordan: A Pilot Case Study. Education Research International, 2018. http://downloads.hindawi.com/journals/edri/2018/7425924.pdf

Syafii, A., Raja, P., \& Nurweni, A. (2016). Blended Learning To Enhance Students' Motivation In Vocational School (Doctoral dissertation, Lampung University). https://core.ac.uk/download/pdf/291529724.pdf

Zainon, H. H., \& Yamat, H. (2021). Effects of Blended Learning on Motivating Secondary Students to Learn English Language: A Pilot Study. Journal of English Language Teaching and Applied Linguistics, 3(2), 23-29.

Cavus, N., \& Kanbul, S. (2010). Designation of Web 2.0 tools expected by the students on technology-based learning environment. Procedia-Social and Behavioral Sciences. 2(2), 5824- 5829. https://doi.org/10.1016/j.sbspro.2010.03.950

Vernadakis, N., Antoniou, P., Giannousi, M., Zetou, E., \& Kioumourtzoglou, E. (2011). Comparing hybrid learning with traditional approaches on learning the Microsoft Office Power Point 2003 program in tertiary education. Computers \& Education. 56(1), 188199. https://doi.org/10.1016/j.compedu.2010.08.007

Stover, K. (2012). Digital collaborative literacy, critical literacy, and writing for social justice: A case study of meaningful learning in a first grade classroom. Doctoral dissertation. The University of North Carolina, Charlotte, USA, https://repository.charlotte.edu//islandora/object/etd:1090

Keengwe, J., Onchwari, G., \& Wachira, P. (2008). The use of computer tools to support meaningful learning. AACE Journal. 16(1), 77-92.

https://www.learntechlib.org/p/23647/

Belmont, R. S., Knudson, D., da Costa, P. H. L., \& dos Santos Lemos, E. (2016). Mastery of Functional Anatomy and meaningful learning in introductory Biomechanics. Revista Práxis. 8(15), 81-91. https://doi.org/10.25119/praxis-8-15-704

Jonassen, D., Howland, J. L., Marra, R. M., \& Crismond, D. P. (2008). Meaningful Learning with Technology. $3^{\text {rd }}$ Edition. Upper Saddle River, New Jersey: Pearson Education.

Jonassen, D. H., Peck, K. L., \& Wilson, B. G. (1999). Learning with technology: A constructivist perspective. Upper Saddle River, NJ: Prentice Hall. 
Yogihati, C. I. (2010). Peningkatan kualitas pembelajaran Fisika Umum melalui pembelajaran bermakna dengan menggunakan peta konsep. Jurnal Pendidikan Fisika Indonesia. 6(2), 104-107. https://doi.org/10.15294/jpfi.v6i2.1121

Jonassen, D., Strobel, J., \& Beng Lee, C. (2006). Everyday problem solving in engineering: Lessons for engineering educators. Journal of Engineering Education. 92(2), 139-151. https://doi.org/10.1002/j.2168-9830.2006.tb00885.x

Grabe, M., \& Grabe, C. (2007). Integrating Technology for Meaningful Learning. 5th Edition. Boston: Houghton Mifflin.

Nouby, A., \& Alkhazali, T. (2017). The effect of designing a blended learning environment on achievement and deep learning of graduate students at the Arabian Gulf University. Open Journal of Social Science. 5(10), 248-260.

https://doi.org/10.4236/jss.2017.510022

McLaughlin, J. E., Gharkholonarehe, N., Khanova, J., Deyo, Z. M. \& Rodgers, J. E. (2015). The impact of blended learning on student performance in a cardiovascular pharmacotherapy course. American Journal of Pharmaceutical Education. 79(2), 1-7. https://doi.org/10.5688/ajpe79224

Melton, B. F., Bland, H. W., \& Chopak-Foss, J. (2009). Achievement and satisfaction in blended learning versus Traditional General Health course designs. International Journal for the Scholarship of Teaching and Learning. 3(1), Article 26.

https://eric.ed.gov/?id=EJ1136602

Luna, Y. M., \& Winters, S. A. (2017). "Why Did You Blend My Learning?" A comparison of student success in lecture and blended learning introduction to Sociology courses". Teaching Sociology. 45(2), 116-130. https://doi.org/10.1177/0092055X16685373

Vasbieva, D. G., Klimova, I. I., Agibalova, E. L., Karzhanova, N. V., \& Bírová, J. (2016). Enhancement of students' vocabulary learning through a Blended Learning Approach. International Electronic Journal of Mathematics Education. 11(5), 1195-1203. https://www.iejme.com/makale/547

Din, R. (2017). Asas Pendidikan dan Kejurulatihan ICT: Integrasi Teori, Media, Teknologi dan Reka Bentuk Pembelajaran. Bangi: Universiti Kebangsaan Malaysia Press; Universiti Kebangsaan Malaysia Press: Bangi, Malaysia.

Din, R. (2012). "Evolusi Web dalam Pengajaran dan Pembelajaran." In Kongres Pengajaran \& Pembelajaran UKM 2012.

Ringle, C. M., Wende, S., \& Becker, J. M. (2015). Bönningstedt: SmartPLS.

Hair, J. F., Sarstedt, M., Hopkins, L. \& Kuppelwieser, V. (2014). Partial least squares structural equation modeling (PLS-SEM): An emerging tool in business research. European Business Review. 26(2), 106-121. https://doi.org/10.1108/EBR-10-2013-0128

Hair, J. F., Thomas, G., Hult, M., Ringle, C. M., \& Sarstedt, M. (2017). A Primer on Partial Least Squares Structural Equation Modeling, 2nd ed. Thousand Oakes, CA: Sage.

Podsakoff, N. P. (2003). Common method biases in behavioral research: a critical review of the literature and recommended remedies. Journal of Applied Psychology. 885(879), 101037. http://dx.doi.org/10.1037/0021-9010.88.5.879

Hair, J. F., Ringle, C. M., \& Sarstedt, M. (2011). PLS-SEM: Indeed a silver bullet. Journal of Marketing theory and Practice. 19(2), 139-152. https://doi.org/10.2753/MTP10696679190202

Hair, J. F., Ringle, C. M., \& Sarstedt, M. (2013). Partial least squares structural equation modeling: Rigorous applications, better results and higher acceptance. Long Range Planning. 46(1-2), 1-12. http://dx.doi.org/10.1016/j.Irp.2013.01.001 